\title{
Distributive Justice and Perceived Organization Support in Indonesian Port Employee
}

\author{
Jimmy Nikiuluw ${ }^{1}$ Syarifudin Tippe ${ }^{2}$ Mahmuddin Yasin $^{3}$ \\ \{Jimmycomm1949@gmail.com $\left.{ }^{1}\right\}$ \\ Universitas Negeri Jakarta, Rawamangun Muka 13220, Indonesia
}

\begin{abstract}
This research intends to know the impacts between distributive justice toward the perception organization support. This research is using causality research design with learning impacts between every variable. Method that is used in this research is to do regression analyzing with distributive justice variable as independence variable and perception organization support as independence variable. The total amount of this research is 185 samples. The result in this research has shown that distributive justice has significant impact toward organization belief. In the result of t-test has shown that distributive justice has affected positively and significantly toward perception organization support, this matter can be occurred because attitude or employee's psychologist situation can be influenced by relation between employee-organization.
\end{abstract}

Keywords: Distributive justice, Perceived Organozation

\section{Introduction}

Indonesia is the biggest archipelago country in the world has 17.508 island with coastline length about $81.00 \mathrm{~km}$ and area of the ocean about 5.8 million $\mathrm{km} 2$ or equal with $3 / 4$ of total area of Indonesia which contain exclusive economic zone (EEZ) as white as 2.7 million $\mathrm{km} 2$ and territorial ocean as big as 3,1million $\mathrm{km} 2$. Because of having a big EEZ region, so that Indonesian economic activity is also in the ocean center. Activity which is connecting with ocean won't be free from harbor according to government rule RI number 692001 serves as a place for ships to lean on, anchored entry of passengers or loading and unloading goods which is completed with safe sail facility and harbor support activities and also as movement place intra and intermodal transportation. The most general harbor activity is entry ships activity for instance loading and unloading ship's goods and passenger. Since 2002-2016 the total amount of the loading and unloading's volume has improved as big as 6,79\%/year and volume of loading of goods has improved as big as 7,63\%/year. The improvement of amount of loading unloading goods is also followed by the total amount ship visits at the harbor which is cultivated in 2017 as much as 319687 ships and as much as 463152 ship visits on harbor which is not cultivated. Every ships visits needs pandu staff when wanting to anchored on harbor, because pandu staff has important job in giving advice, helps and information to captain about ocean situation and also the danger navigation which can be raised up so that cruise navigation can be done safely, orderly, smoothly.

Because the power in the indonesia harbor is really important for Indonesian economy activity smoothness in the ocean, so that human resources which works on the harbor is important enough to be concerned, but right now employee which works in harbor industry 
occurred problem related with perception organizational support. Organizational support theory which is developed by Eisenberger and his colleague suppose that every worker has perception about how an organization care about employee's needs and hopes [1]. "Perceived organizational support (POS) is an expression of the employee's belief that the organization values their contribution and provides for their welfare"[2], the meaning is employee will have perception that organization support them if organization appreciate contribution and serve prosperity for them. The problem related to this perception organizational support can be seen in some employees who do some protest by strike because one of country's company which maintains activity in Indonesia harbor does outsourcing employee and termination of employment action because declining doing outsourcing.

Perception organizational support is expected influence by distributive justice which is gifted by company to employee. "distributive justice is "the extent to which interparty sharing of the rewards from cooperation is fair in view of each party's contribution, commitment, and assumption of responsibility" [3] that definition refers to equal compensation which as big as or fair between some employees, can be seen from contribution, commitment and responsibility of each side. Distributive justice also refers to justice which is accepted by individual in compensation matter from organization especially accuracy of income payment on time and level of benefits. This means that distributive justice is not only referring to compensation quantity and also punishment issued by organization but more into compensation equality which is divided between employees. When employee gets justice in the matter of distributive result for contributing which is already gifted to the company, they will be compare with others in the same workload whether it is fair or not. Distributive justice that feels higher for employee is also cultivating a feeling of organizational support which is higher [4]

\section{Literature Review}

\subsection{Perceive Organization Support}

Perception of organizational support can be defined as organizational support that is perceived (POS) as how far an employee can feel that their contribution is being appreciated by the company and that the company cares about theirs prosperity [5]. according to the POS theory which is raised up by Eisenberger, employee developed perception about how much organization appreciate their contribution and pay attention to their prosperity. [6] Define POS as "employees' conviction that their organizations value their contributions and care about their well-being", means employees who have high POS feel that organization already appreciated and concern towards their prosperity. [7] Argue that organizational support focuses on how much an organization gives support to them [7] Perception level which is felt from organizational support decreased when company doesn't appreciate prosperity continuously and contribution to their employee from. [8] According to the definition from the expert, can be concluded that employee's perception towards organization's awards and support towards them by the their contributions, with the indicators: (1) individual feels that company has appreciated them, (3) individual feels that company has focused on prosperity, (3) individual feels that company supports them, (4) individual give efforts and loyalty

\subsection{Distributive Justice}

Distribution justice is defined as "the extent to which interparty sharing of the rewards from cooperation is fair in view of each party's contribution, commitment and assumption of 
responsibility" [9], means distributive justice referring to equal amount of compensation or justice between several employees, refer to contribution, commitment and responsibility of each side. Distributive justice is part of organization justice, where organization justice defined as individual perception about unjustified treat by the organization to their employees. Distributive justice refers to employee's perception about justice with compensation and other precious result which is distributed in organization [10]

Distributive justice also defined as justice in decision and resources allocation [11]. Resources in that definition refers to: (1) the resources which are needed to do the activities that solve tasks or social-emotional issues; (2) award that strengthen the attitude of the receiver who contributes towards solution of this issue; and (3) interesting awards and resources for receiver and strengthen their loyalty.

"Distributive justice refers to employees" perceived justice concerning the rewards and outcomes they get from an organization" [12], means distributive justice refers to employees' perception which focus to compensation and result that the employees receive from the organization. Based of some definition that has been described, can be synthesized that distributive justice is perception from employees towards compensation and effort which is given by the company that has been equalized and fair with the indicators of: (1) individual perception about justice of compensation, (2) precious result that was given by the company towards the employees, (3) establishment of normative rules, (4) justice in recourses allocation.

\section{Research Methodology}

\subsection{Data}

Data that was used in this research is primer data which obtained by using questioners and shared to the employees who work in the company which responsible to take care of things related to guide service in Indonesia's harbor, called PT Jasa Armada Indonesia

\subsection{Population and Samples}

Population is generation region consist of objects or subjects which have certain quantity and characteristic that has been determined by the researcher to be learned and concluded. Population in this research is every employee from PT Jasa Armada Indonesia with organic or assignment status from the head company in the amount of 341 employees from PT Jasa Armada Indonesia. The samples in this research use the Solvin formula, that is:

$$
\begin{gathered}
n=\frac{N}{1+N(e)^{2}} \\
n=\frac{341}{1+341(0,05)^{2}} \\
n=184,076
\end{gathered}
$$

Explaination:

$\mathrm{n}=$ sample's size

$\mathrm{N}=$ population

$\mathrm{e}=$ percent allowance 
Inaccuracies caused by sampling error that still can be tolerated and wanted. From the calculation of sample's amount, obtained sample in amount of $184.076 \approx 186$ respondents from PT Jasa Armada Indonesia by using the formula above, where error percentage increase 5\%

\subsection{Analytical Technique}

This research is a quantitative associative research, which is by looking for the relation between dependent variable, analyst method that is used is by regency. Justice distribution is an independent variable, meanwhile perception of organization support is dependent variable. Data will be proceeded with the help of SPSS device.

\section{Result and Discussion}

\section{1 t-test}

Table 1 Coefficients

Coefficients $^{\mathbf{a}}$

\begin{tabular}{|c|c|c|c|c|c|}
\hline \multirow[t]{2}{*}{ Model } & \multicolumn{2}{|c|}{$\begin{array}{l}\text { Unstandardized } \\
\text { Coefficients }\end{array}$} & \multirow{2}{*}{\begin{tabular}{|c|}
$\begin{array}{c}\text { Standardized } \\
\text { Coefficients }\end{array}$ \\
Beta \\
\end{tabular}} & \multirow[t]{2}{*}{$\mathrm{t}$} & \multirow[t]{2}{*}{ Sig. } \\
\hline & $\mathrm{B}$ & Std. Error & & & \\
\hline $1 \mathrm{t})$ (Constan & 1,934 & ,222 & & 8,719 & ,000 \\
\hline DJ & ,531 & ,063 & ,529 & 8,434 & ,000 \\
\hline
\end{tabular}

a. Dependent Variable: POS

Based on the result of T-test, can be seen that distributive justice has affect positively and significantly because the amount of T-Test is 8.434 and below 1.653 as for the signification amount of 0.000 which is below the error rate 0.05 . The amount of justice distribution towards perception of organization support is 0.529 .

\subsection{Discussion}

The result of this research shows that distributive justice affects positively and significantly towards perception of organization support. This result is parallel with the previous research result of [13]. Employees that work with harbor industry is required to have various capabilities like marine certification and usually employees have been taught since senior high school, so that devotion felt by the employees who works in harbor industry is big enough, that's why perception of support from organization is a very important thing for the employees. Through that case, justice in resource distribution which is given by the company to the employees is very important to be concerned, because by that justice distribution, the employees will feel appreciated and assessed and when employees receive justice in distribution of contribution that has been given to the organization, they will compare it to other people with the same workload, wether it's fair or not. By comparing it, individual will tend to improve more role behavior or in the other word, they will tend to do more effort. Higher distributive justice was felt by the employees and also grow the feeling of higher organization support [4] 


\section{Conclusion}

Distributive Justice has affected positively and significantly towards perception organizational support. Therefore if the company wants to grow the perception that the company have supported and provided welfare for the employees, the company can focus on recourse distribution which is fair to every employee according to each of their contribution and commitment.

\section{References}

[1] Urbonas, G., Kubilienė, L., Kubilius, R., \& Urbonienè, A. (2015). Assessing The Effects Of Pharmacists' Perceived Organizational Support, Organizational Commitment And Turnover Intention On Provision Of Medication Information At Community Pharmacies In Lithuania: A Structural Equation Modeling Approach. BMC Health Services Research.

[2] Weaver, C. P. (2015). Perceived Organizational Support And Job Overload As Moderators On The Relationship Between Leadership Effectiveness And Job Satisfaction . Emerging Leadership Journeys, Vol. 8 Iss. 1, 79-100.

[3] Norman, U., Ellegaard, C., \& Møller, M. M. (2017). Supplier Perceptions Of Distributive Justice In Sustainable Apparel Sourcing. INTERNATIONAL JOURNAL OF PHYSICAL DISTRIBUTION \& LOGISTICS MANAGEMENT, 368-386.

[4] Mukherjee, K., \& Bhattacharya, R. (2013). Exploring The Mediating Effect Of Organizational Trust Between Organizational Justice Dimensionsand Affective Commitmen. Management And Labour Studies, 63-79.

[5] Deconinck, J. B. (2010). The Effect Of Organizational Justice, Perceived Organizational Support, And Perceived Supervisor Support On Marketing Employees' Level Of Trust. Journal Of Business Research 63.

[6] Simosi, M. (2012). Disentangling Organizational Support Construct. Personnel Review, Vol. 41 No. 3, Pp. 301-320.

[7] Arslaner, E., \& Boylu, Y. (2017). Perceived Organizational Support, WorkFamily/Family-Work Conflict And Presenteeism In Hotel Industry. Tourism Review, Vol. 72 No. 2, , 171-183.

[8] Eisenberger, R., Fasolo, P., \& Lamastro, F. D. (1990). Perceived Organizational Support And Employee Diligence, Commitment, And Innovation. Journal Of Applied Psychology, 75(1), 51-59.

[9] Norman, U., Ellegaard, C., \& Møller, M. M. (2017). Supplier Perceptions Of Distributive Justice In Sustainable Apparel Sourcing. INTERNATIONAL JOURNAL OF PHYSICAL DISTRIBUTION \& LOGISTICS MANAGEMENT, 368-386.

[10] Moorhead, G., \& Griffin, R. W. (2011). Organizational Behavious Managing People And Organizations. Mason: Cengage

[11] Yu Kyoung Park Ji Hoon Song Doo Hun Lim , (2016),"Organizational Justice And Work Engagement: The Mediating Effect Of Self-Leadership", Leadership \& Organization Development Journal, Vol. 37 Iss 6 Pp. -

[12] Hawkar Rashid Arab, Tarik Atan, (2018) "Organizational Justice And Work Outcomes In The Kurdistan Region Of Iraq", Management Decision

[13] Pemecutan, A. A., Dharmanegara, I. B., \& Udayana, I. G. (2016). The Role Of Perceived Organizational Support To Increase Effect Of Organizational Justice Dimension On 
Organizational Citizenship Behavior. IOSR Journal Of Business And Management , 5768. 